\title{
Food and Agriculture Residue (FAR): A Potential Substrate for Tannase and Gallic Acid Production using Competent Microbes
}

Swaran Nandini ${ }^{1}$, Nandini $K^{2}$ and Krishna Sundari $\mathbf{S}^{2 *}$

${ }^{1}$ King Lab Burnett School of Biomedical Sciences, College of Medicine, UCF, USA

${ }^{2}$ Plant \& Microbial Technology (PMT) Group, Biotechnology Department, Jaypee Institute of Information Technology (JIIT), Noida, U.P., India

\begin{abstract}
The study establishes potential of carefully designed formulations of Food and Agricultural Residues (FAR) as most viable and natural substrates for the production of commercially important enzyme tannase and a byproduct gallic acid through Solid State Fermentation (SSF). Novelty of this study was formulation of FAR to achieve better production of tannase and gallic acid by optimizing choice of FAR and its combinations for SSF. Twenty bacterial cultures were successfully isolated and among them sixteen were found with tannase producing ability. Of the entire group of bacteria isolated, two bacterial isolates (B 2.2 and B 2.7) emerged as the best performing candidates in terms of both enzyme and gallic acid production. One Fungal isolate (F1) has also been included in this study from our laboratory collection. A total of 6 FARs (PP, STP, TSP, CH, CC and BP) that are rich in natural tannins were tested in six different combinations. PP with STP in the ratio of 1:1 was found to be most preferred FAR combination by all three isolates (B 2.2, B 2.7, \& F 1) for the production of tannase and gallic acid. Maximum tannase $(19.02 \mathrm{U} / \mathrm{g})$ and gallic acid $(5.32 \mathrm{mg} / \mathrm{g})$ production were achieved by F1, closely followed by B 2.2 and B 2.7. Amongst bacterial isolates, B 2.2 was leading in production of tannase $(13.21 \mathrm{U} / \mathrm{g})$ and gallic acid $(3.51 \mathrm{mg} / \mathrm{g})$ whereas $B 2.7$ proved second best registering $9.15 \mathrm{U} / \mathrm{g}$ of tannase and $3.36 \mathrm{mg} / \mathrm{g}$ of gallic acid. The combination PP with BP was observed to be the second best preferred FAR formulation for the production. Further variations in the formulation of FAR and relative ratios of individual FAR were tested and arrived at a conclusion that PP with STP mixed in a ratio of 1:1 as the most suitable FAR combination for optimal yield of enzyme and its byproduct.
\end{abstract}

Keywords: FAR formulation; FAR; Tannase; Gallic acid; SSF

\section{Introduction}

Enzymes are involved in all aspects of biochemical conversions and are the focal points of biotechnology research. Enzymes catalysed reactions will be 100 million to 10 billion times faster than any normal chemical reaction which makes them highly efficient. In several industries enzymes are used as cost effective eco-friendly substitutes in place of synthetic chemicals for processing complex substrates. Today about 200 enzymes are used in industries for various commercial applications. The global market for industrial enzymes is estimated at 3.3 billion dollars in 2010. This market is expected to reach more than 4 billion dollars by 2015 [1,2]. Tannase (tannin acyl hydrolase) is one such commercially important enzyme. Tannase catalyses the hydrolysis of ester bond and depside bond present in hydrolysable tannins to form glucose and gallic acid [3]. Techniques for production of tannase have been extensively studied and commercial production of tannase was achieved using synthetic tannic acid as substrate. Industrial bioconversion of tannic acid is accomplished by enzyme tannase producing gallic acid (3, 4, 5-tri hydroxyl benzoic acid), a pharmaceutically important intermediate used for the preparation of trimethoprim (antibacterial drug), pyrogallol, propyl gallate. Certain industrially important products derived by the action of tannases are high grade leather, clarified beer and fruit juice, coffee flavoured soft drinks, premium branded tea, paper, cosmetics etc. other applications include detannification of industrial effluents [4-7]. Tannases are produced by fungal as well as bacterial isolates. Depending on the isolate/strain studied and the culture conditions provided, the enzyme was expressed at various quantities and exhibited different levels of activity, $\mathrm{pH}$ and temperature stability and half-life. Amongst a wide variety of microbes tested, fungi from genus Aspergillus [8,9] and bacteria belonging to the genus Bacillus $[10,11]$ are mostly used by commercial industries. The industrial process makes use of chemical tannic acid for tannase production but this process involving synthetic substrates has adverse environmental consequences. Conventionally gallic acid is also produced chemically by acid hydrolysis of synthetic tannic acid and suffers from disadvantages like high cost to yield ratio and low purity. Alternatively, gallic acid can be produced by the microbial hydrolysis of tannic acid (synthetic or natural) by using the enzyme tannase $[3,6,12]$. Hence any advancement in making the production of tannase more economical and environmental friendly would have far reaching benefits. This has led to generating interest in identifying natural sources for tannic acid that can be effectively utilized by microbes and produce the enzyme tannase and gallic acid during the fermentation process. It takes a lot of research efforts to produce tannase with properties in sync for optimized industrial output and is produced through microbial fermentation using natural sources of tannic acid thus reducing the dependency on synthetic tannic acid.

The present manuscript is an effort to assess the employment of Fruit and Agricultural Residues (FAR) as a natural and inexpensive substrate for the production of tannase and gallic acid and strengthen the methods of microbial hydrolysis. Hence the study was focused on isolating native microbes from soil and fruit wastes having the ability to produce tannase and gallic acid using natural sources of tannins/ tannic acid. FAR explored in the study were Pomegranate Peel (PP),

*Corresponding author: Krishna Sundari S, Plant \& Microbial Technology (PMT) Group, Biotechnology Department, Jaypee Institute of Information Technology (JIIT), A-10, Sector-62, NOIDA, 201307, U.P., India, Tel: 0120-2594206; E-mail: krishna.sundari@jiit.ac.in

Received November 29, 2014; Accepted December 09, 2014; Published December 12, 2014

Citation: Nandini S, Nandini KE, Krishna Sundari S. (2014) Food and Agriculture Residue (FAR): A Potential Substrate for Tannase and Gallic Acid Production using Competent Microbes. J Bioprocess Biotech 5: 193 doi: 10.4172/2155-9821.1000193

Copyright: (C) 2014 Greetham D. This is an open-access article distributed unde the terms of the Creative Commons Attribution License, which permits unrestricted use, distribution, and reproduction in any medium, provided the original author and source are credited. 
Banana Peel (BP), Spent Tea Powder (STP), Tamarind Seed Powder (TSP), Corn Husk (CH) and Coconut Coir (CC) which are reported in literature to have high tannin content. Till date none of the reported literature formulated SSF combinations using these above mentioned substrates together as an alternative source for synthetic tannic acid. So the uniqueness of this study lies in formulating various combinations of FAR for SSF (Solid State Fermentation) on the basis of available tannins and carbohydrate content and to incorporate both tested and unreported natural tannic acid sources originating from FAR. The objective was to support microbial growth on FAR while achieving enhanced production of tannase and gallic acid. The study establishes dual benefit/applicability by: a. producing economically important products utilizing a resource (FAR), whose accumulation is a burden on environment and $\mathrm{b}$. offering a viable and economical alternative to synthetic tannic acid for the production of tannase and gallic acid economically.

\section{Materials and Methods}

\section{Sample collection}

Multiple soil samples were collected from selected areas of fruit and vegetable market's dump site near Paschim Vihar, New Delhi, India. Surface soil debris was removed and a $15 \mathrm{~cm}$ hollow metal borer was plunged into the soil to lift the soil lump from $5-10 \mathrm{~cm}$ depth. Randomly collected soil samples were pooled thoroughly mixed and air dried for five days. For all subsequent studies including physicochemical analysis and microbial isolation representative soil sample was drawn from the air dried sample stock.

\section{Physico-chemical analysis of soil samples}

At the time of sampling, the color and texture of the soil were observed and recorded. $\mathrm{pH}$ of the soil sample was analyzed by mixing the soil with de-ionized water in the ratio of 1:2 (soil:distilled water) as suggested by Clesceri et al. [13]. All analysis were carried out in triplicates.

\section{Isolation of tannase producing bacterial strains}

$1 \mathrm{~g}$ of air dried soil sample was seeded in $10 \mathrm{ml}$ of nutrient broth for isolating the bacterial cultures and incubated at $37^{\circ} \mathrm{C} .50 \mu \mathrm{l}$ of soil soup was spread over two nutrient agar plates (Plate $1 \&$ Plate 2 ) and kept for overnight incubation at $37^{\circ} \mathrm{C}$. Post incubation, ten physically distinct colonies were selected from each plate $(1 \& 2)$ and analyzed for their tannase producing ability. These twenty colonies were inoculated in different test tubes containing $10 \mathrm{ml}$ nutrient broth supplemented with $0.2 \%$ filter sterilized tannic acid and incubated overnight at $37^{\circ} \mathrm{C}$ (Figure 1). Second round of isolation was carried out using 50 $\mu \mathrm{l}$ of inoculums from enrichment culture and spreading them over nutrient agar plates supplemented with $2 \%(\mathrm{w} / \mathrm{v})$ filter sterilized tannic acid. Addition of tannic acid to nutrient agar forms a tannin-protein complex. Bacteria producing tannase cleave this complex thus forming a dark brown colored zone around the colonies [14]. Sixteen distinct colonies that exhibited tannase producing ability were taken ahead for biochemical characterization.

\section{Fungal culture for SSF studies}

Fungal isolate (F1) from the laboratory culture collection with reports for high tannase producing ability [30] was used as the fungal counterpart in these SSF studies. The culture was maintained constantly on Czapek-Dox agar plate supplemented with filter sterilized tannic acid $(2 \%, w / v)$, incubated at $30^{\circ} \mathrm{C}$ with periodic sub-culturing.

\section{Biochemical characterization of bacterial isolates}

All sixteen morphologically distinct bacterial isolates were characterized by microscopy and biochemical assays. Cell morphology and gram nature of the isolated bacterial colonies was identified using gram staining technique. To characterize the bacteria up to genus level following biochemical tests were performed as per the protocols mentioned in Bergey's manual [15]. All biochemical tests were performed in triplicate and for all such tests fresh overnight grown culture broth / single CFU were used as per the demands of the experiment.

Triple sugar iron test: Inoculum of bacterial cultures (pure) was stabbed into the TSI slant separately and incubated overnight at $37^{\circ} \mathrm{C}$. Lactose fermenting nature of the bacteria will be indicated by yellow slant/yellow butt (acid/acid reaction), whereas non-lactose fermenters will result in pink/yellow or yellow/yellow (if sucrose is fermented). Blackening of the butt due to $\mathrm{H}_{2} \mathrm{~S}$ production may mask the acid reaction (yellow) in the butt.

Motility test: Motility media was prepared and inoculum of bacterial culture was stabbed through center of the medium (one-half of the depth) and test tubes were incubated at $37^{\circ} \mathrm{C}$ for $18-48 \mathrm{~h}$. A visually diffuse growth spreading from the line of inoculation indicates motility.

Catalase test: A loopful of bacterial culture was smeared on a slide containing a drop of $3 \%$ hydrogen peroxide. Catalase positive isolates were expected to produce bubbles due to breakdown of hydrogen peroxide into oxygen and water.

Lactose and sucrose test: Lactose broth was inoculated with bacterial culture and incubated overnight at $37^{\circ} \mathrm{C}$. The solubilization of lactose/sucrose by bacterial isolates result in production of acids which will be indicated by change in color from red-orange color of the indicator phenol red to yellow.

Starch hydrolysis test: Bacterial isolates were grown on starch agar medium. Post inoculation, the plates were flooded with iodine and appearance of a clear zone indicates starch hydrolyzing capability of the organism.

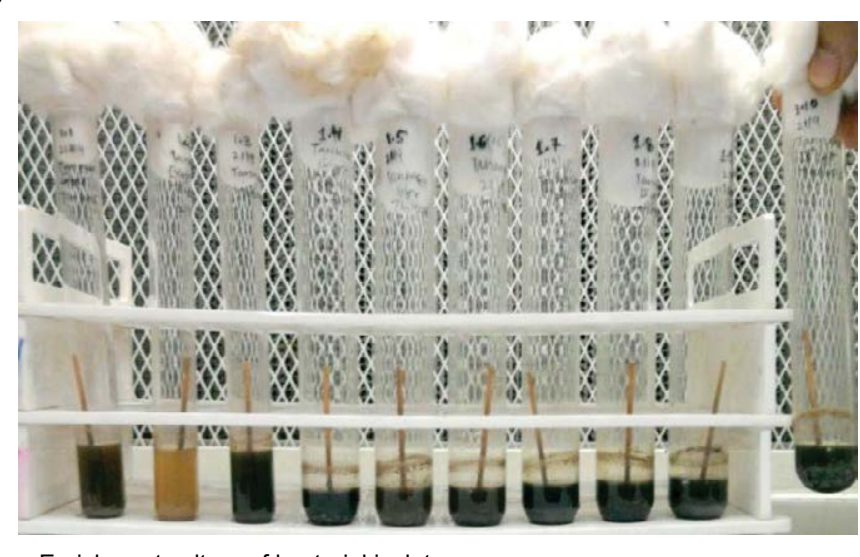

Enrichment culture of bacterial isolate

Tubes a) B 1.1 ; b) B 1.2 ; c) B 1.3 ; d) B 1.4 ; e) B 1.5 ; f) B 1.6 ; g) B 1.7 ; h) B 1.8 ; i) B 1.9 ; j) B 1.10

Figure 1: Different bacterial isolates grown on nutrient broth supplemented tannic acid 
Citrate test: Simmon citrate slants were inoculated with bacterial isolates by stab culture method and incubated at $37^{\circ} \mathrm{C}$ for $48 \mathrm{~h}$. A positive test for citrate utilization is represented by the development of deep blue color within 24 to $48 \mathrm{~h}$.

Indole test: Peptone broth was inoculated with the bacterial culture. After overnight inoculation at $37^{\circ} \mathrm{C}$, Kovac's reagent was added. Positive result was marked by the presence of red or red-violet color on the surface of alcohol layer in culture broth. Development of yellow color indicates negative result.

Bile esculin test: Bile esculin slant was inoculated by stab culture method and incubated overnight at $37^{\circ} \mathrm{C}$ for $48 \mathrm{~h}$. Hydrolysis of esculin media will turn media into dark brown or black color registering a positive result.

\section{Selection of bacterial isolates for tannase production on synthetic media}

Preliminary screening of bacterial isolates was studied by estimating the gallic acid as an indicator for tannase producing ability where the isolates were screened for production of gallic acid- a byproduct of tannic acid hydrolysis. For the screening study all the sixteen isolates were grown on synthetic media (nutrient broth supplemented with $2 \%$ filter sterile tannic acid), incubated for $36 \mathrm{~h}$. Post incubation, the culture broth was centrifuged at 8000 RPM to pellet out the bacterial biomass. The culture supernatant thus obtained was analyzed for gallic acid content and it was expressed in $\mu \mathrm{g} / \mathrm{ml}$. As a further step of confirmation, a quantitative measurement was made where diameter of the coloured zone was recorded for the bacterial isolates grown on tannic acid $(2 \%, w / v)$ supplemented nutrient agar plates. Single point inoculations of a single CFU of each bacterial culture were made on separate plates in triplicates and incubated at $37^{\circ} \mathrm{C}$. Zone diameter of top five bacterial isolates (isolates that showed very distinct and strong zone around colonies) was recorded.

\section{Designing of FAR based substrate for SSF}

FAR proposed in this study were Banana Peels (BP), Pomegranate Peels (PP), Spent Tea Leaves Powder (STP), Tamarind Seed Powder (TSP), Coconut Coir (CC) and Corn Husk (CH). These FARs were collected from the local market and dried separately in the hot air oven till the moisture was completely removed. The dried FAR were ground to form a fine powder and stored for further use. Selection and formulation of FAR combinations for SSF experiments was based on the composition of mineral content, natural tannins as well as the available essential nutrients present in these FARs as evidenced from the published literature (Table 1) [16-22]. Further combination of these FARs was designed so as to provide a balanced medium where all essential nutrients are present for obtaining optimal microbial growth and enzyme production.

A three stage approach was attempted for designing/formulating the FAR combinations. In the first stage, the microbial isolates were grown on individual FAR to check the efficiency in utilizing the complex substrate (FAR) by the organism for its growth and production of tannase and gallic acid. In the next stage, the combinations (2 FARs mixed in 1:1 ratio) were proposed so as to provide all the essential nutrients for enhanced/optimal production and also based on the results of preliminary studies on production of tannase and gallic acid on individual FAR. Further top two combinations of FAR on which maximum production was obtained were taken and combined in a different proportion $(3: 1)$ to know if the relative proportions of FAR influence the yield of tannase and/or gallic acid.

\section{Formulation of FAR for solid state fermentation}

Solid state fermentation by three microbial cultures i.e. two bacterial isolates (B 2.2 and B 2.7, native isolates) and one fungal isolate (F 1, from laboratory collection) were carried out on FAR to examine the tannase and gallic acid production by utilizing FAR as an alternate substrate. $2 \mathrm{~g}$ of FAR was individually taken in jam bottle of $250 \mathrm{ml}$ capacity. Wetting media (containing the following salts (in $\mathrm{g} / \mathrm{l}): \mathrm{K}_{2} \mathrm{HPO}_{4}, 0.76 ; \mathrm{KCl}, 0.26 ; \mathrm{MgSO}_{4}, 0.26 ; \mathrm{NaNO}_{3}, 1.5 ; \mathrm{FeSO}_{4}$ and $\mathrm{ZnSO}_{4}, 0.005$ ) was added on the basis of moisture retention capacity of the particular FAR. The contents were autoclaved at $15 \mathrm{lb}, 120^{\circ} \mathrm{C}$ for $20 \mathrm{~min}$ and cooled. $1 \mathrm{ml}$ of overnight grown bacterial isolates were added separately to the jam bottle and incubated for $48 \mathrm{~h}$. CFU count of bacterial culture used for inoculation were $32 \times 10^{8} \mathrm{CFU} / \mathrm{ml}$ in case of B 2.2 and $48 \times 10^{8} \mathrm{CFU} / \mathrm{ml}$ for B 2.7 respectively. Media for fungal inoculation was prepared following similar procedure mentioned above. Two stubs of $5 \mathrm{~mm}$ diameter of the growing mycelium of 7 day old fungal culture were placed upside down (mycelia bearing side of the stub facing down i.e., touching the SSF substrate) on the SSF media and incubated at $35^{\circ} \mathrm{C}$ for $72 \mathrm{~h}$. The results were analyzed and further combinations of FAR were designed to get maximum production of tannase and gallic acid. The tested combination included PP with BP/ STP/TSP/CC in the ratio 1:1 and PP with STP and BP and STP in the ratio of (3:1). Extraction of extracellular tannase produced was carried out by mixing the contents of jam bottle after SSF with $30 \mathrm{ml}$ of citrate buffer of pH 5.5 and kept for $2 \mathrm{~h}$ stirring. The content was centrifuged and the supernatant was used as the crude extract for the estimation of tannase and gallic acid. All the experiments were performed in triplicates and average values are reported.

Significant difference between means were determined by Anova two factor with replication and T-test (two samples assuming equal variance) using Microsoft Excel. The significance of differences was defined at $\mathrm{P} \leq 0.05$.

\section{Estimation of tannase activity}

Tannase activity was determined using spectrophotometric method based on the formation of chromogen between rhodanine and gallic acid (that is released by the action of enzyme-tannase on substrate i.e. methyl gallate). $100 \mu \mathrm{l}$ of crude extract was used for the estimation of enzyme and absorbance was recorded against blank at $520 \mathrm{~nm}$ using Shimadzu UV-1800 spectrophotometer [23]. Tannase activity was calculated based on the standard graph of gallic acid and expressed in terms of $\mathrm{U} / \mathrm{g}$ of substrate.

\section{Gallic acid estimation}

Gallic acid was estimated by spectrophotometric method using methanolic rhodanine at $520 \mathrm{~nm}$ using spectrophotometer (Shimadzu UV-1800) as per the procedure Sharma et al. [23]. Gallic acid content was calculated on the basis of standard curve of gallic acid. Gallic acid is expressed as $\mathrm{mg} / \mathrm{g}$ of substrate.

\section{Results and Discussion}

\section{Physicochemical analysis of soil samples}

The collection of the soil samples was done during the early monsoon season (i.e. July-August). $\mathrm{pH}$ of the soil sample was slightly alkaline i.e. 7.37 and soil sample was brown, coarse, porous and rich in humus content. Soil sampling was done from the sub surface as such sub-surface soil usually possesses active microbial population in abundance. 


\begin{tabular}{|c|c|c|c|c|c|c|}
\hline Components & Pomegranate peel & Tamarind seed & Banana peel & Spent tea & Corn Husk & Coconut coir \\
\hline Total solids (\%) & 94.50 & & 95.66 & 91.80 & & \\
\hline Moisture (\%) & 5.40 & $9.4-11.3$ & 6.70 & & 15 & 25.5 \\
\hline Total Sugars (\%) & 17.70 & $11.3-25.3$ & & & & \\
\hline Reducing Sugars (\%) & 4.34 & 7.40 & & & & \\
\hline Protein (\%) & 4.90 & $13.3-26.9$ & 4.77 & 18.60 & & \\
\hline Crude Fiber (\%) & 16.30 & $7.4-8.8$ & 31.70 & 23.60 & & \\
\hline Fat content $(\%)$ & 1.26 & $4.5-16.2$ & & & & \\
\hline Ash (\%) & 3.40 & $1.60-4.2$ & 8.50 & 5.87 & 8.26 & 9.00 \\
\hline Carbohydrate (\%) & & 73.68 & 59.00 & - & & \\
\hline Total Phenol (\%) & 8.10 & & & & & \\
\hline Hydrolysable tannins (\%) & 6.11 & & & & & \\
\hline Condensed tannins (\%) & 1.20 & & & & & \\
\hline Tannins (\%) & 7.31 & 20.00 & $30-40$ & $13-17$ & & 29 \\
\hline Calcium & & $36.60-786(\mathrm{mg} / 100 \mathrm{~g})$ & $19.20 \mathrm{mg} / \mathrm{g}$ & 1.5 & 0.4 & \\
\hline Phosphorous & & $165-312(\mathrm{mg} / 100 \mathrm{~g})$ & $2.3 \mathrm{mg} / \mathrm{g}$ & 0.53 & 0.5 & \\
\hline Magnesium & & $28.20-214(\mathrm{mg} / 100 \mathrm{~g})$ & & & & \\
\hline Potassium & & $272.8-610(\mathrm{mg} / 100 \mathrm{~g})$ & $78.12 \mathrm{mg} / \mathrm{g}$ & & 0.9 & \\
\hline Sodium & & $19.2-28.8(\mathrm{mg} / 100 \mathrm{~g})$ & $24.30 \mathrm{mg} / \mathrm{g}$ & & & \\
\hline Copper & & $1.6-19.0(\mathrm{mg} / 100 \mathrm{~g})$ & & & & \\
\hline Iron & & $6.30-45.5(\mathrm{mg} / 100 \mathrm{~g})$ & $0.61 \mathrm{mg} / \mathrm{g}$ & & & \\
\hline Zinc & & $7.0(\mathrm{mg} / 100 \mathrm{~g})$ & & & & \\
\hline Manganese & & $0.68-12.1(\mathrm{mg} / 100 \mathrm{~g})$ & $76.20 \mathrm{mg} / \mathrm{g}$ & & & \\
\hline Organic Matter & & $12.10 \mathrm{mg} / \mathrm{g}$ & $91.50 \%$ & & & \\
\hline Crude Lipid & & & $1.70 \%$ & & & \\
\hline Oxalate & & & $0.51 \mathrm{mg} / \mathrm{g}$ & & & \\
\hline Hydrogen Cyanide & & & $1.33 \mathrm{mg} / \mathrm{g}$ & & & \\
\hline Phytate & & & $0.28 \mathrm{mg} / \mathrm{g}$ & & & \\
\hline Saponins & & & $24 \mathrm{mg} / \mathrm{g}$ & & & \\
\hline Starch $(\%)$ & & $33.10 \%$ & & & & \\
\hline
\end{tabular}

Table 1: Chemical composition of individual FAR included in SSF studies

\section{Isolation of tannase producing bacterial strains}

Direct soil culturing was carried out in nutrient broth. Consequent secondary culturing was by plating method via serial dilution yielded a total of twenty physically distinct bacterial colonies which were then analyzed for their tannase producing ability on tannic acid supplemented nutrient agar plates. This step eliminated four isolates as they were not able to grow on the tannic acid supplemented plates. The growth of the remaining sixteen isolates indicated that they are capable of degrading tannic acid into their simpler compounds such as gallic acid. Further these sixteen bacterial isolates were classified according to their gram nature and morphology.

\section{Physiological typing (characterization) of bacterial strains}

Gram staining and microscopy studies revealed that among sixteen isolates ten were found to be gram positive (B 1.1, B 1.3, B 1.4, B 1.5, B 1.7, B 1.8, B 1.10, B 2.1, B 2.5 and B 2.10) and six (B 1.2, B 1.9, B 2.2, B 2.6, B 2.7 and B 2.8) were gram negative. Based on cell morphology the cultures were classified as Bacilli and Cocci. Further the results of microscopic and biochemical test performed on different isolates were tabulated in Table 2. Results of biochemical assays of important isolates were represented in the figure (Figure 2). From the biochemical analysis we concluded that the gram positive isolates could belong to the genus Bacillus, Lactobacillus, Enterococcus or Streptococcus and that the gram negative isolates could belong to the genus Klebsiella, Escherchia or Citrobacter. All these species of bacteria have been reported to possess tannase producing ability and were reported in the literature [24-28].

\section{Selection of bacterial isolates for tannase production on synthetic media}

To select the bacterial isolates for tannase producing ability we used gallic acid as a marker. The isolate which produce higher amount of gallic acid as the end product was assumed to have higher tannase producing ability as gallic acid is a byproduct produced when tannase hydrolyses tannic acid. This study indicated among sixteen bacterial isolates, the strains B 1.1, B 1.7, B 2.2, B 2.7 and B 2.8 were the top five producers of gallic acid (Figure 3 ). These strains were better producers of gallic acid and in turn they are considered as better producers of tannase.

Further top five bacterial isolates thus selected were tested for their ability to produce zone of clearance on nutrient agar plate containing $2 \%$ tannic acid supplemented to confirm the gallic acid production results. This confirmation was needed as the gallic acid could not be the exact indicator of tannase producing ability. Gallic acid produced by the organisms sometimes further broken down to the simpler chemical compounds.

A visible dark green halo of gallic acid surrounding the bacterial colony was observed and measured as zone diameter. This was produced by the cleavage of tannin-protein complex; cleavage of this complex by bacteria producing tannase forms a zone around the colonies. Based on zone diameter 5 bacterial isolates produced statistically significant (ANOVA, t-test) result of which two bacterial isolates B 2.2 and B 2.7 that showed maximum zone diameter were selected for further studies on RAR based SSF (Table 3). This was confirmed by the production of zone of clearance around the bacterial growth and brown coloration after prolonged incubation [14]. It was evident from the literature that the strains having ability to utilize tannic acid to maximum extent will be the better producer of tannase which was also confirmed by observing high correlation between the zone of clearance with the 
Citation:Nandini S, Nandini KE, Krishna Sundari S. (2014) Food and Agriculture Residue (FAR): A Potential Substrate for Tannase and Gallic Acid Production using Competent Microbes. J Bioprocess Biotech 5: 193 doi:10.4172/2155-9821.1000193

Page 5 of 8

\begin{tabular}{|c|c|c|c|c|c|c|c|c|c|c|c|}
\hline $\begin{array}{l}\text { Bacterial } \\
\text { isolates }\end{array}$ & $\begin{array}{c}\text { Gram } \\
\text { nature }\end{array}$ & Shape & TSI & Citrate & Bile Esculin & Sucrose & Indole & Motility & Starch & Catalase & Lactose \\
\hline B 1.1 & + ve & Cocci & + ve & $-v e$ & + ve & - ve & - ve & + ve & - ve & - ve & + ve \\
\hline B 1.2 & - ve & Cocci & + ve & - ve & - ve & - ve & + ve & - ve & - ve & - ve & + ve \\
\hline B 1.3 & + ve & Bacilli & + ve & + ve & + ve & - ve & - ve & + ve & + ve & $-v e$ & + ve \\
\hline B 1.4 & + ve & Bacilli & + ve & + ve & + ve & - ve & - ve & $+v e$ & - ve & - ve & + ve \\
\hline B 1.5 & + ve & Cocci & + ve & $+v e$ & + ve & - ve & - ve & $+v e$ & $-v e$ & $-v e$ & + ve \\
\hline B 1.7 & + ve & Cocci & + ve & $+v e$ & + ve & - ve & + ve & + ve & - ve & - ve & + ve \\
\hline B 1.8 & + ve & Bacilli & + ve & + ve & + ve & - ve & + ve & + ve & - ve & - ve & + ve \\
\hline В 1.9 & - ve & Cocci & + ve & + ve & + ve & - ve & - ve & + ve & - ve & - ve & + ve \\
\hline B 1.10 & + ve & Bacilli & + ve & + ve & + ve & - ve & - ve & + ve & - ve & - ve & + ve \\
\hline B 2.1 & + ve & Bacilli & + ve & - ve & + ve & - ve & - ve & + ve & - ve & - ve & $+v e$ \\
\hline B 2.2 & $-v e$ & Cocobacilli & $+v e$ & + ve & + ve & - ve & - ve & $+v e$ & - ve & - ve & + ve \\
\hline B 2.5 & + ve & Cocci & $+v e$ & $+v e$ & + ve & - ve & - ve & + ve & $-v e$ & - ve & + ve \\
\hline B 2.6 & - ve & Cocci & $+v e$ & $+v e$ & + ve & - ve & - ve & $+v e$ & - ve & - ve & + ve \\
\hline B 2.7 & - ve & Bacilli & + ve & + ve & + ve & - ve & + ve & $+v e$ & - ve & - ve & + ve \\
\hline B 2.8 & - ve & Cocci & + ve & + ve & + ve & - ve & - ve & $+v e$ & - ve & - ve & + ve \\
\hline B 2.10 & + ve & Bacilli & + ve & + ve & + ve & - ve & - ve & + ve & - ve & - ve & + ve \\
\hline
\end{tabular}

Table 2: Physiological typing (characterization) of sixteen tannase producing bacterial isolates
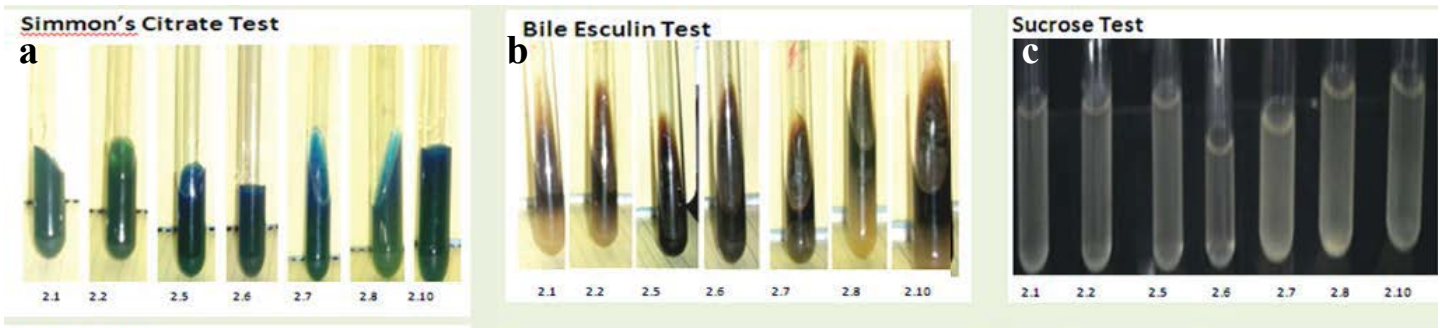

Lactose Test
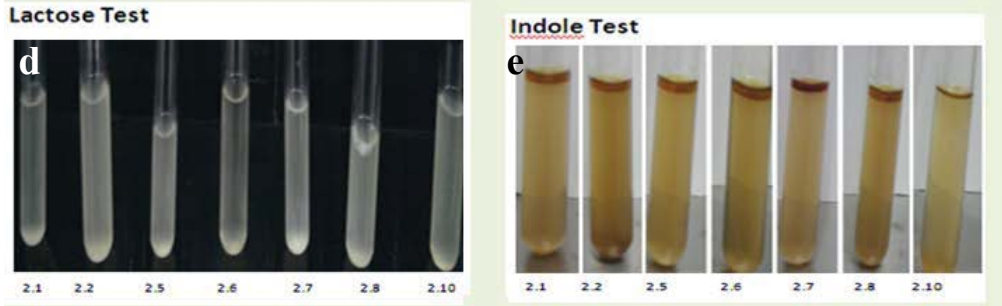

Triple Sugar Iron Test
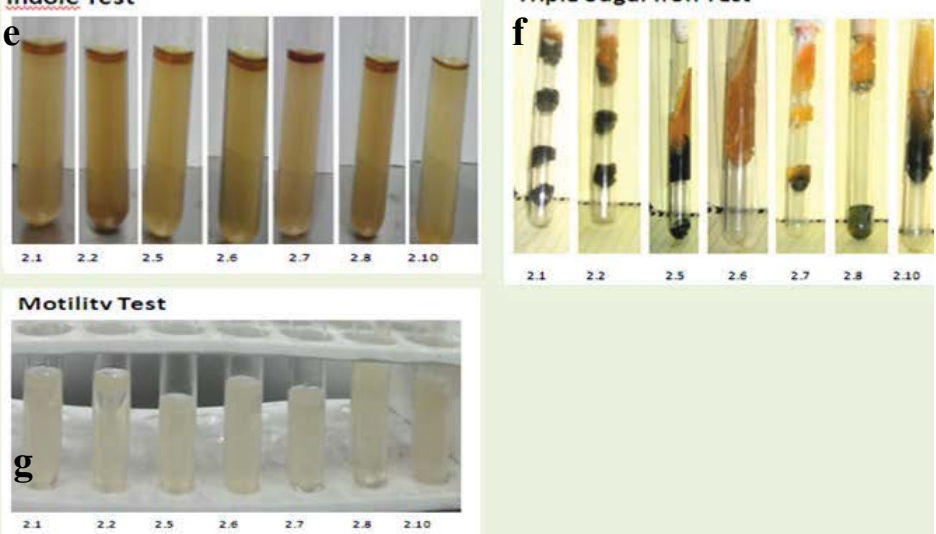

a) Simmons Citrate test; b)Bile Esculine test; c) Sucrose test; d) Lactose test; e) Indole test; f) Triple sugar iron test; g) Motility test and sequence of bacterial culture inoculation from left to right is: B 2.1; B 2.2; B 2.5;B 2.6; B 2.7; B 2.8; B 2.10 and was maintained same for all the tests conducted.

Figure 2: Biochemical assays of important bacterial isolates

quantitative enzyme production $[4,29]$. The growth of the two bacterial isolates (B 2.2 and B 2.7) and fungal isolate F1 on tannic acid agar plate were shown in the figure (Figure 4 ) and these isolates were selected for SSF studies.

\section{Formulation of FAR for Solid state fermentation}

The choice of substrates was made on the basis of tannin content and reducing sugar estimation previously carried out in our lab and reported [30]. The use of some of these FAR as alternative substrate to synthetic tannic acid was also evidenced by the reported literature [3133]. A three stage approach was followed to design the combination of FAR for SSF study. The first stage of choosing FARs was based on the published data of the available nutrients (Table 1) and estimated results of tannin and reducing sugar content from our previous studies [30] with FAR. This designing of FAR combination is the uniqueness of our study as the FARs were complex substrates and attaining balance of exact concentration of macro and micro nutrient is not feasible. Hence efforts were made to formulate such SSF substrate combination where required basic nutrients along with the principal substrate for enzyme i.e. tannase is present in moderate quantities along with readily metabolizable sugar to support the microbial growth in SSF.

In the first stage the organisms are grown on individual FAR. Amongst the individual FARs tested, PP and STP gave maximum yield (statistically significant at $\mathrm{P} \leq 0.05$ ) (Table 4 ). Between bacterial 


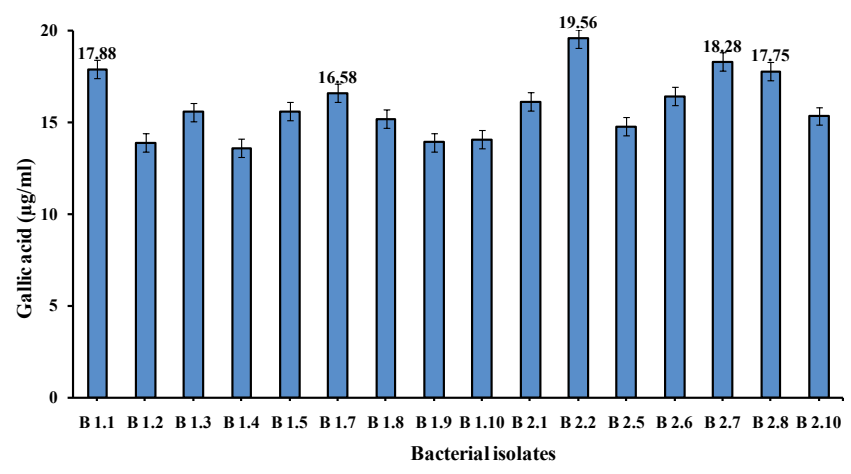

Figure 3: Gallic acid production of bacterial isolates on synthetic media through Smf

\begin{tabular}{|c|c|}
\hline Bacterial isolates & Zone diameter $(\mathbf{m m})$ \\
\hline B 2.2 & $17 \pm 0.37^{\mathrm{a}}$ \\
\hline B 2.7 & $15 \pm 0.38^{\mathrm{b}}$ \\
\hline B 1.1 & $13 \pm 0.45^{\mathrm{c}}$ \\
\hline B 2.8 & $11 \pm 0.43^{\mathrm{d}}$ \\
\hline B 1.7 & $10 \pm 0.57^{\mathrm{e}}$ \\
\hline
\end{tabular}

Data with different superscripts $(a, b, c, d$ and e) differ significantly at the probability level $p \leq 0.05$.

Table 3: Top five tannase producing bacterial isolates identified based on zone diameter

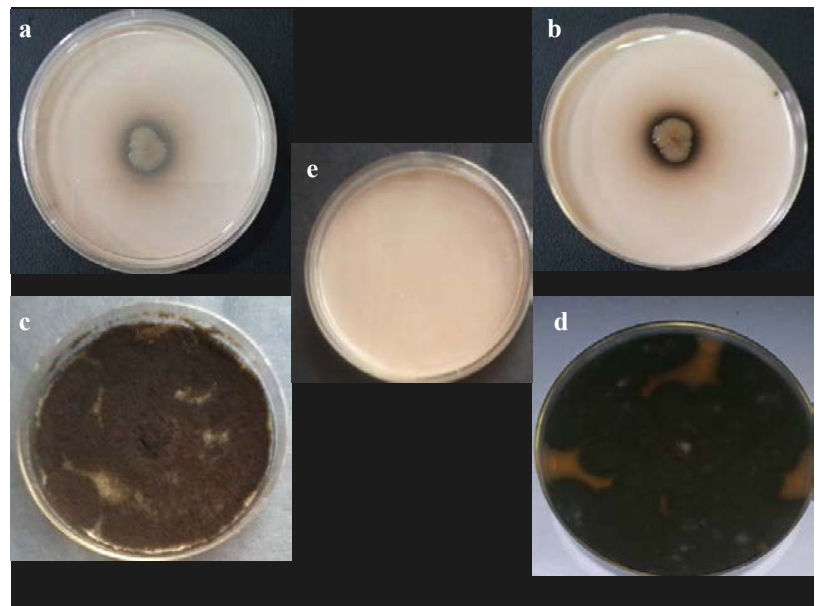

a) Bacterial isolate $B$ 2.7; b) Bacterial isolate B 2.2; c) Front view of fungal isolate $\mathrm{F} 1$; d) dorsal view of $\mathrm{F} 1$ and $\mathrm{e}$ ) uninoculated control

Figure 4: Growth of the bacterial and fungal isolate on tannic acid supplemented agar plate

and fungal isolates, F1 resulted in significantly higher production (ANOVA, T-test at $\mathrm{P} \leq 0.05$ ) of tannase and gallic acid. Maximum tannase production observed by $\mathrm{F} 1$ was of $8.49 \mathrm{U} / \mathrm{g}$ on PP, followed by $7.62 \mathrm{U} / \mathrm{g}$ on STP, $5.75 \mathrm{U} / \mathrm{g}$ on TSP and $4.01 \mathrm{U} / \mathrm{g}$ on BP. Similar trend was observed for gallic acid production in case of PP and STP, 2.88 $\mathrm{mg} / \mathrm{g}$ on PP and $2.52 \mathrm{mg} / \mathrm{g}$ on STP. Whereas the amount of gallic acid production on TSP and BP were almost similar i.e. TSP $(1.07 \mathrm{mg} / \mathrm{g})$ and BP $(1.13 \mathrm{mg} / \mathrm{g})$. Among bacterial cultures B 2.2 was better producer of tannase $(6.88 \mathrm{U} / \mathrm{g})$ and gallic acid $(2.06 \mathrm{mg} / \mathrm{g})$ on PP. Further the preference of FAR by all organisms showed similar pattern.

In the second stage FAR combinations were made in such a way that the tannin content available should be less than $15 \%$ as the higher concentration of tannins will also hinder the tannase production. Also it was ensured that PP is included in all the combinations, as it was the found to be most favored SSF substrate (as compared to other FARs studied) for tannase and gallic acid production (Table 4). Significantly higher tannase production was observed in two FAR combinations (PP with STP and PP with BP) that involve three FARs i.e. PP, STP and BP. Highest production of tannase observed was $19.21 \mathrm{U} / \mathrm{g}$ and gallic acid was $5.32 \mathrm{mg} / \mathrm{g}$ on PP with STP using F 1. This was followed by PP and BP i.e. $11.23 \mathrm{U} / \mathrm{g}$ of tannase activity and $1.87 \mathrm{mg} / \mathrm{g}$ of gallic acid (Table 5).

Two combinations were proposed in the third stage i.e. PP with STP and BP with STP in the ratio of 3:1. This experiment was designed to check whether the production in these FAR combinations was enhanced by STP/BP/PP. The results indicated that PP is most supporting FAR for the production as compared to other FAR but only at the optimum concentration. The increase in PP concentration resulted in decline in tannase as well as gallic acid production (Table 5). This could be due to higher tannin content and sugar content. It has been reported that high tannin and sugar content will have inhibitory effect on tannase production [32,34-37]. The decrease in activity beyond optimum substrate concentration i.e. 3:1 could be due to increase in total sugar and tannin content with the increase in concentration of substrate might lead to substrate toxicity in the medium. The results obtained were in agreement with the reported literature [38]. FAR used in the present study are rich in carbon sources and increase in substrate concentration leads to increase in total sugar content. It is observed that the increase in carbon sources creates osmotic stress to depress enzyme synthesis and which could be a reason for the reduction in tannase production at higher substrate concentration [39]. Concentrations of other nutrient supply of the FAR also contribute to the inhibitory effect on the tannase production such as $\mathrm{Ca}^{+2}, \mathrm{Zn}^{+2}, \mathrm{Fe}^{+3}$.

\section{Conclusions}

Our study was the first attempt to formulate combination of FAR as an alternate substrate for microbial production of tannase and gallic acid. The FAR selected in the study were PP, STP, TSP, BP, CC and $\mathrm{CH}$. FAR formulation for SSF experiment was designed in three stages. This study revealed that the FAR formulation of PP with STP (1:1 ratio) was the best among the six formulations attempted for all the microbial isolates. Maximum production of tannase by F1 on this FAR formulation was $19.02 \mathrm{U} / \mathrm{g}$ and gallic acid was $5.32 \mathrm{mg} / \mathrm{g}$. Further the bacterial isolates also have shown equally good amount of production. Among the bacterial isolates B 2.2 has shown maximum production of tannase $(13.21 \mathrm{U} / \mathrm{g})$ and gallic acid $(3.51 \mathrm{mg} / \mathrm{g})$ on the same FAR formulation. The study revealed that these FAR and their combinations surely contribute as cheap and efficient raw material for production of tannase and gallic acid by native isolates. The results also indicate that there is an ample of scope for further research to optimize the process parameters of SSF to achieve enhanced production. However, there is a need to check tannin utilized by these isolates on all possible FAR combinations before it can replace synthetic tannic acid in industrial processes.

\section{Acknowledgement}

The author Dr. K.E. Nandini gratefully acknowledges Department of Biotechnology, Govt. of India, New Delhi for fellowship of DBT-RA and financial support to carry out the research work. Authors express their sincere thanks to the 
Citation:Nandini S, Nandini KE, Krishna Sundari S. (2014) Food and Agriculture Residue (FAR): A Potential Substrate for Tannase and Gallic Acid Production using Competent Microbes. J Bioprocess Biotech 5: 193 doi:10.4172/2155-9821.1000193

Page 7 of 8

\begin{tabular}{|c|c|c|c|c|c|c|}
\hline \multirow{2}{*}{ FAR } & \multicolumn{3}{|c|}{ Tannase activity (U/g) } & \multicolumn{3}{|c|}{ Gallic acid (mg/g) } \\
\hline & F1 & B 2.2 & B 2.7 & F1 & B 2.2 & B 2.7 \\
\hline $\mathrm{CH}$ & $3.22 \pm 0.04^{\mathrm{a}}$ & - & - & $1.89 \pm 0.03^{a}$ & - & - \\
\hline CC & $3.43 \pm 0.49^{a}$ & $2.90 \pm 0.49^{a}$ & $1.98 \pm 0.32^{\mathrm{a}}$ & $0.98 \pm 0.12^{\mathrm{b}}$ & $0.80 \pm 0.16^{a}$ & $0.77 \pm 0.08^{a}$ \\
\hline BP & $4.01 \pm 0.50^{\mathrm{a}}$ & $4.44 \pm 0.99^{a}$ & $3.77 \pm 0.76^{b}$ & $1.13 \pm 0.08^{b}$ & $0.86 \pm 0.06^{a}$ & $0.87 \pm 0.06^{a}$ \\
\hline TSP & $5.75 \pm 0.34^{b}$ & $3.10 \pm 0.53^{a}$ & $2.57 \pm 0.50^{b}$ & $1.07 \pm 0.05^{b}$ & $0.84 \pm 0.05^{a}$ & $0.82 \pm 0.04^{a}$ \\
\hline STP & $7.62 \pm 0.37^{c}$ & $4.98 \pm 0.33^{b}$ & $3.66 \pm 0.33^{c}$ & $2.52 \pm 0.07^{c}$ & $1.76 \pm 0.09^{b}$ & $1.29 \pm 0.07^{b}$ \\
\hline PP & $8.49 \pm 0.21^{d}$ & $6.88 \pm 0.48^{c}$ & $4.05 \pm 0.36^{c}$ & $2.88 \pm 0.04^{d}$ & $2.06 \pm 0.40^{b}$ & $1.58 \pm 0.03^{c}$ \\
\hline
\end{tabular}

Data with different superscripts $(a, b, c, d$ and e) differ significantly at the probability level $p \leq 0.05$.

Table 4: Production of tannase and gallic acid by SSF on FAR

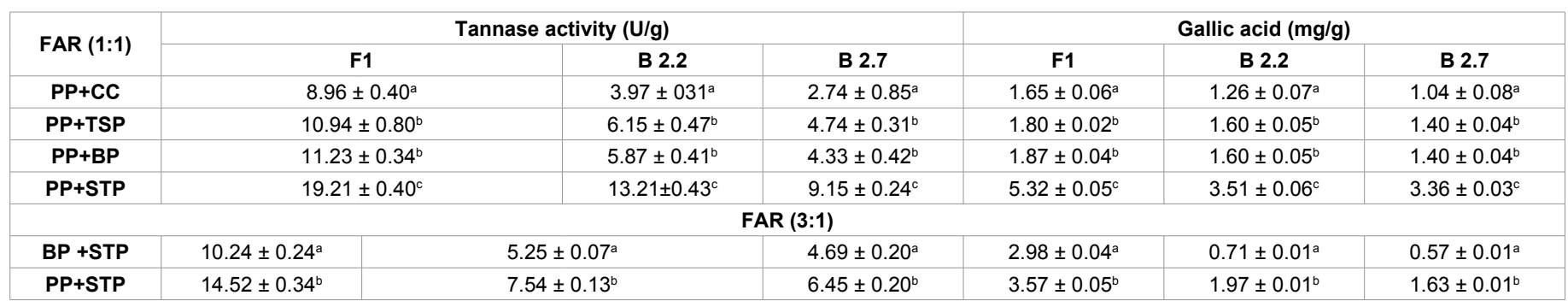

Data with different superscripts ( $a, b, c$ and d) differ significantly at the probability level $p \leq 0.05$

Table 5: Production of tannase and gallic acid by SSF on different formulations of FAR

Honorable Vice Chancellor, JIIT, NOIDA and Head of the Department and staff, Biotechnology Department, JIIT, NOIDA for their kind support.

\section{References}

1. Li S, Yang X, Yang S, Zhu M, Wang X (2012) Technology prospecting on enzymes: application, marketing and engineering. Comput Struct Biotechnol J 2: e201209017.

2. Gurung N, Ray S, Bose S, Rai V (2013) A broader view: microbial enzymes and their relevance in industries, medicine, and beyond. Biomed Res Int 2013: 329121.

3. Pinto GAS, Leite SGF, Terzi SC, Couri S (2001) Selection of tannase-producing Aspergillus niger strains. Braz J Microbiol 32: 24-26.

4. Lekha PK, Lonsane BK (1997) Production and application of tannin acyl hydrolase: state of the art. Adv Appl Microbiol 44: 215-260.

5. Mukherjee G, Banerjee R (2006) Effects of temperature, $\mathrm{pH}$ and additives on the activity of tannase produced by a co-culture Rhizopus oryzae and Aspergillus foetidus. World J Microbiol Biotechnol 22: 207-212.

6. Aguilar CN, Rodríguez R, Gutiérrez-Sánchez G, Augur C, Favela-Torres E et al. (2007) Microbial tannases: advances and perspectives. Appl Microbiol Biotechnol 76: 47-59.

7. Beniwal V, Kumar A, Sharma J, Chhokar V1 (2013) Recent advances in industrial application of tannases: a review. Recent Pat Biotechnol 7: 228-233.

8. Batra A, Saxena RK (2005) Potential tannase producers from the genera Aspergillus and Penicillium. Process Biochem 40: 1553-1557.

9. Purohit JS, Dutta JR, Nanda RK, Banerjee R (2006) Strain improvement for tannase production from co-culture of Aspergillus foetidus and Rhizopus oryzae. Bioresour Technol 97: 795-801.

10. Ayed L, Hamdi M (2002) Culture conditions of tannase production by Lactobacillus plantarum. Biotechnol Lett 24: 1763-1765.

11. Beniwal V, Chhokar V, Singh N, Sharma J (2010) Optimization of process parameters for the production of tannase and gallic acid by Enterobacter cloacae MTCC 9125. J American Sci 6: 389-397.

12. Lokeshwari N, Reddy RD (2010) Microbiological production of gallic acid by a mutant strain of Aspergillus oryzae using cashew husk. Pharmacophore 1 112-122.

13. Clesceri LS, Greenberg AE, Trussel RR (1989) Standard methods for the analysis of water and wastewater, 17th edition, American Public Health Association.

14. Kumar R, Kumar A, Nagpal R, Sharma J, Kumari A (2010) A novel and sensitive plate assay for screening of tannase-producing bacteria. Ann Microbiol 60: $177-179$
15. Garrity GM, Bell JA, Lilburn TG (2004) Taxonomic outline of the prokaryotes. Bergey's manual of systematic bacteriology. Second edition. Volume 3 Springer, New York, Berlin, Heidelberg.

16. Tejano EA (1985) State of the Art of Coconut Coir Dust and Husk Utilization (General Overview). National Workshop on Waste Utilization, Coconut Husk 1984, Philippine Coconut Authority, Diliman, Quezon City, Philippines.

17. Tartrakoon T, Chalearmsan N, Vearasilp T, Meulen U (1999) The nutritive value of banana peel (Musa sapieutum L.) in growing pigs, In Sustainable technology development in animal agriculture. Deutscher Tropentag, Berlin.

18. El-Siddig, Gunasena HPM, Prasad BA, Pushpakumara DKNG, Ramana KVR et al. (2006) Tamarind, Tamarindus indica. Southampton Centre for underutilized crops, Southampton, UK.

19. Aguilar CN, Aguilera-Carbo A, Robledo A, Ventura J, Belmares R, et al. (2008) Production of antioxidant nutraceuticals by solid-state cultures of pomegranate (Punica granatum) peel and creosote bush (Larreatri dentata) leaves. Food Technol Biotechnol 46: 218-222.

20. Sabu A, Augur C, Swati C, Pandey A (2006) Tannase production by Lactobacillus sp. ASR-S1 under solid-state fermentation. Process Biochem 41 575-580.

21. Viuda-Martos M, Fernández-López J, Pérez-Álvarez JA (2010) Pomegranate and its many functional components as related to human health: A Review. Comp Rev Food Sci Food Safety 9: 635-654.

22. Israel AU, Ogali RE, Obot IB (2011) Extraction and characterization of coconut (Cocos nucifera L.) coir dust. Songklanakarin J Sci Technol 33: 717-724.

23. Sharma S, Bhat TK, Dawra RK (2000) A spectrophotometric method for assay of tannase using rhodanine. Anal Biochem 279: 85-89.

24. Mondal KC, Banerjee R, Pati BR (2000) Tannase production by Bacillus licheniformis. Biotechnol Lett 20: 767-769.

25. Mondal KC, Banerjee D, Banerjee R, Pati BR (2001) Production and characterization of tannase from Bacillus cereus KBR9. J Gen Appl Microbio 47: 263-267.

26. Selwal MK, Yadav A, Selwal KK, Aggarwal NK, Gupta R, et al. (2010) Optimization of cultural conditions for tannase production by Pseudomonas aeruginosa IIIB 8914 under submerged fermentation. World J Microbiol Biotechnol 26: 599-605.

27. Belur PD, Gopal M, Nirmala KR, Basavaraj N (2010) Production of nove cell-associated tannase from newly isolated Serratia ficaria DTC. J Microbiol Biotechnol 20: 732-736.

28. Bradoo S, Gupta R, Saxena RK (1996) Screening of extracellular tannase producing fungi: development of a rapid and simple plate assay. J Gen App Microbiol 42: 325-329. 
Citation:Nandini S, Nandini KE, Krishna Sundari S. (2014) Food and Agriculture Residue (FAR): A Potential Substrate for Tannase and Gallic Acid Production using Competent Microbes. J Bioprocess Biotech 5: 193 doi:10.4172/2155-9821.1000193

29. Nandini KE, Gaur A, Sundari SK (2013) The suitability of natural tannins from food and agricultural residues (FAR) for producing industrially importan Tannase and Gallic acid through microbial fermentation. Int J Agric Food Sci Technol 4: 999-1010

30. Sabu A, Pandey A, Daud MJ, Szakacs G (2005) Tamarind seed powder and palm kernel cake: two novel agro residues for the production of tannase under solid state fermentation by Aspergillus niger ATCC 16620. Bioresour Techno 96: $1223-1228$

31. Jana A, Maity C, Halder SK, Mondal KC, Pati BR, et al. (2012) Tannase production by Penicillium purpurogenum PAF6 in solid state fermentation of tannin-rich plant residues following OVAT and RSM. Appl Biochem Biotechnol 167: 1254-1269.

32. Saad H, Charrier-el Bouhtoury F, Pizzi A, Rode K, Charrier B, et al. (2012) Characterization of pomegranate peels tannin extractives. Industrial crops and products 40: 239-246.

33. Lekha PK, Lonsane BK (1994) Comparative titres, location and properties of tannin acyl hydrolase produced by Aspergillus niger PKL 104 in solid-state, liquid surface and submerged fermentations. Process Biochem 29: 497-503.
34. Banerjee R, Mukherjee G, Patra KC (2005) Microbial transformation of tanninrich substrate to gallic acid through co-culture method. Bioresour Technol 96 : 949-953.

35. Rodrigues TH, Dantas MA, Pinto GA, Gonçalves LR (2007) Tannase production by solid state fermentation of cashew apple bagasse. Appl Biochem Biotechnol 137-140: 675-88.

36. Srivastava A, Kar R (2009) Characterization And Application Of Tannase Produced By Aspergillus niger ITCC 6514.07 On Pomegranate Rind. Braz J Microbiol 40: 782-789.

37. Raaman N, Mahendran B, Jaganathan C, Sukumar S,Chandrasekaran V (2010) Optimisation of extracellular tannase production from Paecilomyces variotii. World J Microbiol Biotechnol 26:1033-1039.

38. Kumar R, Sharma J, Singh R (2007) Production of tannase from Aspergillus ruber under solid-state fermentation using jamun (Syzygium cumini) leaves. Microbiol Res 162: 384-390.

39. Lokeswari N, Raju KJ, Pola S, Bobbarala V (2010) Tannin acyl hydrolase from Trichoderma viride. Int J Chem Anal Sci 1: 106-109. 